\title{
Analysis of Cation Migration Channels in $\mathrm{PbWO}_{4}$
}

\author{
Volodymyr Shevchuk, Ihor Kayun \\ Department of Electronics and Computer Technologies, \\ Ivan Franko National University of Lviv \\ Drahomanova St 50, 79005 Lviv, Ukraine \\ e-mail: shevchuk@electronics.Inu.edu.ua
}

\begin{abstract}
The analysis of possible $\mathbf{W}$-ions migration in $\mathrm{PbWO}_{4}$ with sheelite type structure was realized using the TOPOS calculation complex program. The temperature dependence of migration channel lengths and theirs evolution with change of unit cell parameters were considered.
\end{abstract}

Index Terms-PbWO ${ }_{4}$; sheelite; electromigration; TOPOS; W-migration path; migration channel

\section{INTRODUCTION}

The analysis method of crystalline space and totality of voids and channels in crystal structure based on Voronoi tessellation was realized in TOPOS program package [1] for ionic electrical migration in different crystals. The topological atomic analysis, visualization of cationic migration path, and some basic concepts on micro-level investigation of the mobile ion migrations in crystal lattice using TOPOS calculation complex programs was carried out for real oxide crystals in particular with sheelite type structure in our works [2, 3].

In the present paper with the aim to analysis of microstructure and features of the migration ways of $\mathrm{W}$-ions in $\mathrm{PbWO}_{4}$ were considered a numerous literature data and our experimental results on X-ray crystallographic investigations. We calculated and constructed the W-migration path in compounds and considered a temperature changes of characteristic elementary parameters of cationic transference specifically the length of elementary channels. The evolution of the calculated migration channel lengths was analyzed with changing of a unit cell parameters. Consideration of chemical and structural factors and visualization of conduction pathways are promoted the determination of mechanisms and other spatial features of ions migration in crystals. This approach allowed also the forecast of crystal properties and applications.

\section{EXPERIMENTAL AND CALCULATION PROCEDURE}

Our $\mathrm{PbWO}_{4}$ undoped single crystal (sheelite type structure, space group $\mathrm{C}_{4 h}^{6}-\mathrm{I}_{1} / a$ ) was grown by Czochralski technique [4]. Other $\mathrm{PbWO}_{4}$ compounds (sheelite type structure) were prepared by a different authors and methods (see Table I). The structural data and densities of $\mathrm{PbWO}_{4}$ (Table I) obtained from the X-ray diffraction (XRD) data. Our XRD analysis was performed on a STOE STADI P powder diffraction system. Arrays of experimental intensities and diffraction angles were obtained using the mentioned diffractometer equipped with a linear position sensitive detector PSD in a modified Guinier geometry scheme in Bragg-Brentano transmission mode.
Conditions of the measurements: monochromatic $\mathrm{CuK} \alpha_{1}$ radiation $(\lambda=1.540598 \AA)$; bent Johann type [111] Gemonochromator; $\omega / 2 \theta$-scan; $2 \theta$-range $4^{\circ} \leq 2 \theta \leq 120^{\circ}$; step $0.480^{\circ}$ $(2 \theta)$; step scan time $250 \mathrm{~s}$. Other XRD-measurement details were described previously [15]. The search for structural data was performed using Pearson's Crystal Data [16].

In the work using the program package TOPOS 4.0 the $\mathrm{W}$ ionic migration maps for the $\mathrm{PbWO}_{4}$ crystals were constructed. Possible migration paths of $\mathrm{W}$ ions in the structure crystals at different temperatures (ref. [14]) and changing of a unit cell volume (data in the Table I) were analyzed.

TABLE I. SOME CRYSTALlographic AND PhySiCAL DATA FOR THE $\mathrm{PBWO}_{4}$ COMPOUNDS USED FOR CALCULATIONS

\begin{tabular}{|c|c|c|c|c|c|}
\hline \multirow{2}{*}{ Ref } & \multirow{2}{*}{$\begin{array}{c}\text { Method of } \\
\text { growing }\end{array}$} & \multicolumn{2}{|c|}{ Unit cell param., $\AA$} & \multirow{2}{*}{$\begin{array}{c}\text { Unit cell } \\
\text { volume, } \AA^{3}\end{array}$} & \multirow{2}{*}{$\begin{array}{l}\text { Density, } \\
\mathrm{g} \mathrm{cm}^{-3}\end{array}$} \\
\hline & & $a$ & $c$ & & \\
\hline $\begin{array}{l}\text { Our } \\
\text { data }\end{array}$ & Czochralski & 5.4601 & 12.0425 & 359.02 & 9.0662 \\
\hline$[5]$ & Czochralski & 5.4560 & 12.02 & 357.81 & 9.0968 \\
\hline$[6]$ & Czochralski & 5.4360 & 11.9570 & 353.33 & 9.2122 \\
\hline [7] & $\begin{array}{l}\text { mechanical } \\
\text { alloying }\end{array}$ & 5.4661 & 1.20779 & 360.87 & 9.0198 \\
\hline$[8]$ & $\begin{array}{c}\text { conventional } \\
\text { sol.-st. reaction }\end{array}$ & 5.4597 & 12.0420 & 358.95 & 9.0679 \\
\hline [9] & Czochralski ? & 5.4646 & 12.0479 & 359.77 & 8.8177 \\
\hline$[10]$ & natural & 5.4450 & 12.0495 & 357.24 & 9.1113 \\
\hline [11] & $\begin{array}{c}\text { complex } \\
\text { polymerization }\end{array}$ & 5.4637 & 12.0654 & 360.18 & 9.0371 \\
\hline$[12]$ & $\begin{array}{l}\text { precipitation } \\
\text { method }\end{array}$ & 5.4645 & 12.0553 & 359.98 & 9.0420 \\
\hline [13] & polycrystal & 5.3851 & 11.7223 & 339.94 & 9.5751 \\
\hline [14] & Czochralski & 5.4632 & 12.0482 & 359.60 & 9.0516 \\
\hline
\end{tabular}

The map of voids and channels is consistent with experimental data. The basic concepts for description of the voids and channel are the following: elementary void (channel), and closely related terms of form and radius of void, significant elementary void (channel). The Voronoi polyhedron of atom (geometric image atom), as suggested by the value of the second moment inertia $(\mathrm{G})$.

Elementary crystal void is an area of crystal unit cell, the center of which is one of the vertexes of Voronoi polyhedron. The major (ZA) and minority (ZC) elementary voids with sequence numbers $\mathrm{N}$ (ZAN and $\mathrm{ZCN}$ ) are considered. To show preference for a $Z A N$ voids. For the calculation we used the radii of the ion $\mathrm{W}^{6+}(0.56 \AA)$ at the coordination number 4 , $\mathrm{Pb}^{2+}(1.43 \AA$ \& $)$ at the coordination number 8 , and $\mathrm{O}^{2-}(1.36 \AA$ ) [17]. For W (as near to Mo) the value of the parameter $G$ is 
$0.0830(1)$ [18]. The migration way is determined as the set of elementary voids and lines of elementary channels. It can be infinite along the 1D-, or 2D, or 3D-channel-net. The conductivity map formed by the migration pathways of possible charge carriers.

\section{RESULTS AND DISCUSSION}

Analysis of the calculation data in most cases the continuous pathways for the $\mathrm{Pb}$ - and $\mathrm{W}$-ions in the $\mathrm{PbWO}_{4}$ compound with sheelite type structure were not observed. But for some crystal (structure data $[11,19]$ ) the continuous pathways for the W-ions were observed (Fig. 1). The technological condition of compound preparation play the principal role in considered cases and determined the variation unit cell volumes and void distances (Fig. 2) correspondingly. The great meaning of unit cell volume stimulate formation the continuous ways for the $\mathrm{W}$-ions probable migrations.

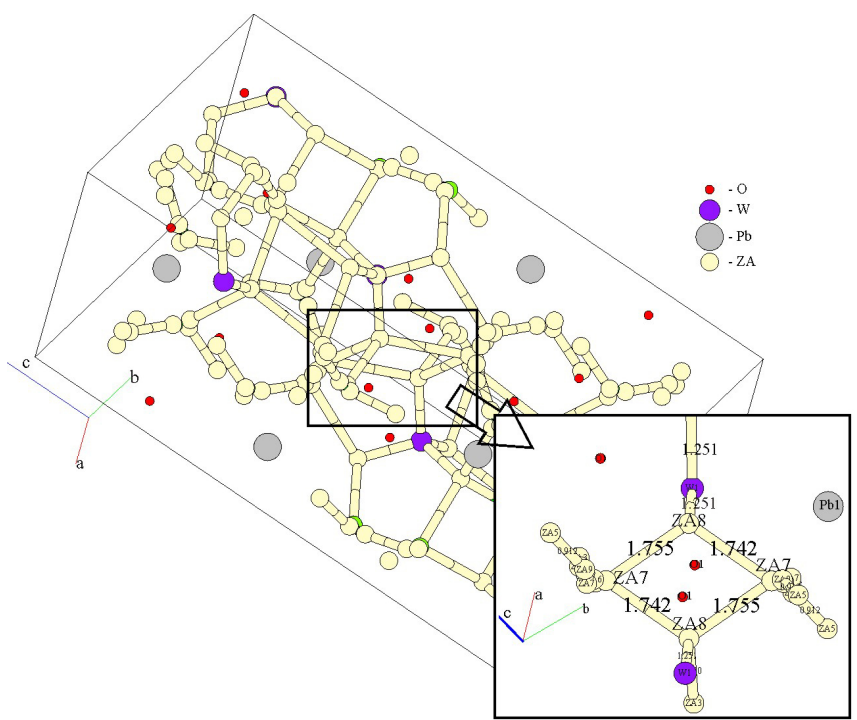

Figure 1. Probable migration pathways calculated at RT for the W ions in $\mathrm{PbWO}_{4}$ using crystal data [11] and fragment (inset) of channel migrations.

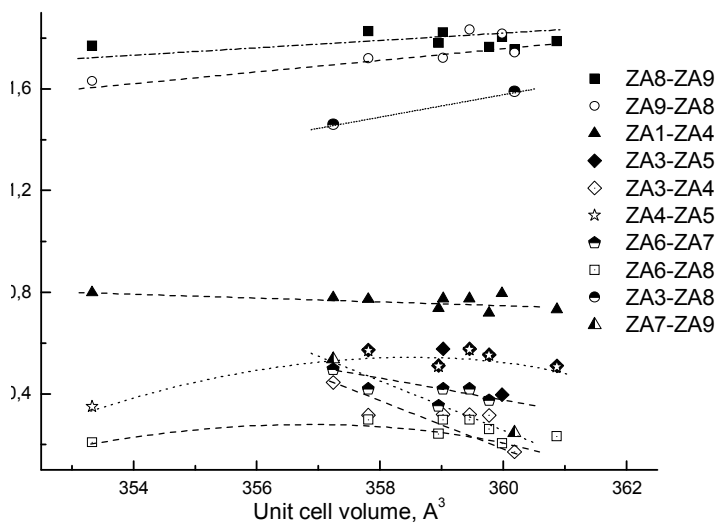

Figure 2. Evolution of some voids distances at RT with changing of a unit cell volume for the $\mathrm{PbWO}_{4}$ prepared by different methods (see Table 1).

The Fig. 3 ( $a, b, c)$ show the temperature dependencies of the distances between ZAN-voids in possible migration channels of $\mathrm{W}$-ions. The calculations were performed for X-ray crystal structure data [14].

The curves on Fig. 3 demonstrate specific temperatures about 100 and $200 \mathrm{~K}$. At these temperatures the change of the declination curves (change of the temperature dependence law) are observed. Up to the temperature $100 \mathrm{~K}$ the rising of channel length are not observed. In temperature range 100-200 K are occur the nearly linear increasing/decreasing of the channel lengths (links or the same as distances between neighboring voids). These features of temperature behavior changing of the distance voids in $\mathrm{PbWO}_{4}$ are connectable to changing of other physical and structural [14] properties of crystal at abovementioned temperatures.
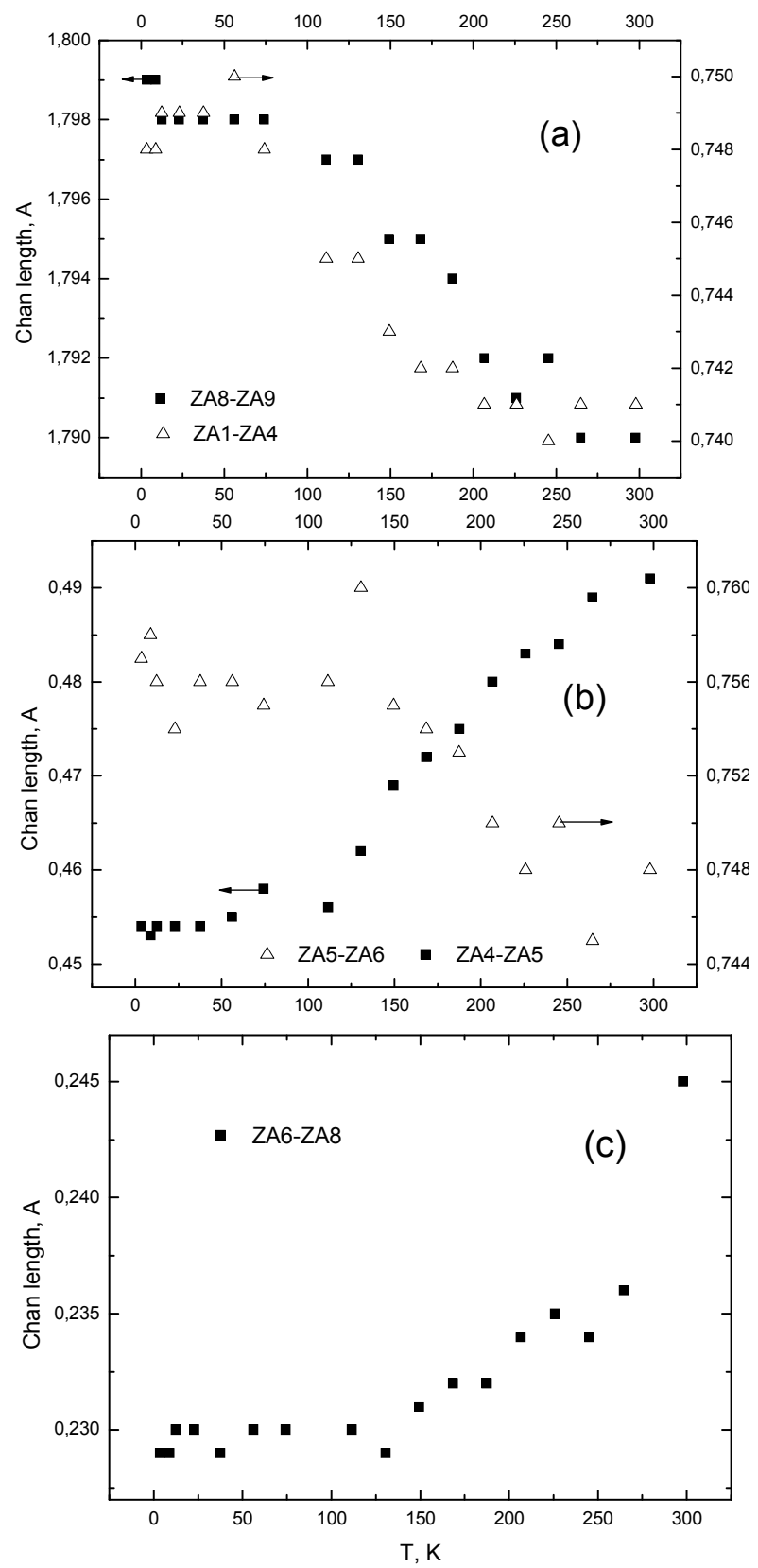

Figure 3. Temperature dependencies $(\mathrm{a}, \mathrm{b}, \mathrm{c})$ of the some void distances. Calculation was performed using data [14]. 
The calculation data of a ZAN voids and suitable connections for some crystals are presented in the Table II.

TABLE II. POSITION OF CALCULATION VOIDS AND CHANNEL LENGTHS FOR W-MIGRATION AT RT IN THE $\mathrm{PBWO}_{4}$ WITH SHEELITE TYPE STRUCTURE

\begin{tabular}{|c|c|c|c|c|c|c|}
\hline \multirow{2}{*}{ Ref } & \multirow{2}{*}{ ZAN } & \multicolumn{3}{|c|}{ Positions } & \multirow{2}{*}{ Void bound } & \multirow{2}{*}{$\begin{array}{c}\text { Length, } \\
\AA\end{array}$} \\
\hline & & $\mathbf{x}$ & $\mathbf{y}$ & $\mathbf{Z}$ & & \\
\hline \multirow{14}{*}{$\begin{array}{l}\text { Our } \\
\text { data }\end{array}$} & ZA1 & 0.87586 & 0.31459 & 0.76202 & ZA1-ZA4 & 0.774 \\
\hline & \multirow{2}{*}{ ZA3 } & \multirow{2}{*}{0.68489} & \multirow{2}{*}{0.11120} & \multirow{2}{*}{0.66520} & ZA3-ZA4 & 0.318 \\
\hline & & & & & ZA3-ZA5 & 0.577 \\
\hline & \multirow{2}{*}{ ZA4 } & \multirow{2}{*}{0.67351} & \multirow{2}{*}{0.15972} & \multirow{2}{*}{0.67883} & ZA4-ZA1 & 0.774 \\
\hline & & & & & ZA4-ZA3 & 0.318 \\
\hline & \multirow{2}{*}{ ZA5 } & \multirow{2}{*}{0.63829} & \multirow{2}{*}{0.17805} & \multirow{2}{*}{0.63473} & ZA5-ZA3 & 0.577 \\
\hline & & & & & ZA5-ZA4 & 0.574 \\
\hline & ZA6 & 0.96585 & 0.68436 & 0.65422 & ZA6-ZA7 & 0.419 \\
\hline & ZA7 & 0.00000 & 0.75000 & 0.66330 & ZA7-ZA6 & 0.420 \\
\hline & \multirow{3}{*}{ ZA8 } & \multirow{3}{*}{0.04775} & \multirow{3}{*}{0.77717} & \multirow{3}{*}{0.67051} & ZA8-ZA6 & 0.297 \\
\hline & & & & & ZA8-ZA9 & 1.721 \\
\hline & & & & & ZA8-ZA9 & 1.832 \\
\hline & \multirow{2}{*}{ ZA9 } & & & & ZA9-ZA8 & 1.832 \\
\hline & & 0.40656 & 0.91419 & 0.56001 & ZA9-ZA8 & 1.721 \\
\hline & ZA1 & 0.88833 & 0.31673 & 0.75716 & ZA1-ZA4 & 0.974 \\
\hline & & & & & ZA3-ZA4 & 0.172 \\
\hline & ZA3 & $0.6 / 8 / 1$ & 0.11980 & 0.66192 & ZA3-ZA8 & 1.590 \\
\hline & & & & & ZA4-ZA1 & 0.974 \\
\hline & ZA4 & 0.67298 & 0.14663 & 0.66884 & ZA4-ZA3 & 0.172 \\
\hline & & & & 064312 & ZA5-ZA4 & 0.337 \\
\hline & ZAS & 0.65228 & 0.15900 & 0.64312 & ZA5-ZA9 & 0.912 \\
\hline & & & & & ZA7-ZA8 & 1.742 \\
\hline [11] & ZA7 & 0.04524 & 0.77524 & 0.67696 & ZA7-ZA8 & 1.755 \\
\hline & & & & & ZA7-ZA9 & 0.247 \\
\hline & & & & & ZA8-ZA3 & 1.590 \\
\hline & ZA8 & 0.34485 & 0.66345 & 0.69036 & ZA8-ZA7 & 1.742 \\
\hline & & & & & ZA8-ZA10 & 1.251 \\
\hline & 740 & 096631 & 069363 & 066302 & ZA9-ZA5 & 0.912 \\
\hline & LA9 & 0.96031 & 0.09363 & 0.66302 & ZA9-ZA7 & 0.247 \\
\hline & ZA10 & 0.50000 & 0.75000 & 0.62500 & ZA10-ZA8 & 1.251 \\
\hline & ZA1 & 0.89058 & 0.31376 & 0.76319 & ZA1-ZA4 & 0.880 \\
\hline & ZA3 & 0.66678 & 0.13115 & 0.66200 & ZA3-ZA9 & 1.600 \\
\hline & ZA4 & 0.66142 & 0.15593 & 0.66900 & ZA4-ZA1 & 0.880 \\
\hline & ZA5 & 0.64307 & 0.16663 & 0.64698 & ZA5-ZA6 & 0.879 \\
\hline & $7 \Delta 6$ & & & 065512 & ZA6-ZA5 & 0.879 \\
\hline & ZA6 & $0.9 / 34 /$ & 0.70447 & 0.05512 & ZA6-ZA8 & 0.187 \\
\hline [10] & & & & & ZA8-ZA6 & 0.187 \\
\hline [19] & ZA8 & 0.03452 & 0.77155 & 0.66553 & ZA8-ZA9 & 1.852 \\
\hline & & & & & ZA8-ZA9 & 1.945 \\
\hline & & & & & ZA9-ZA10 & 1.202 \\
\hline & 740 & 040691 & 089911 & 056405 & ZA9-ZA3 & 1.600 \\
\hline & LA9 & 0.40691 & 0.89911 & 0.56495 & ZA9-ZA8 & 1.852 \\
\hline & & & & & ZA9-ZA8 & 1.945 \\
\hline & ZA10 & 0.50000 & 0.75000 & 0.62500 & ZA10-ZA9 & 1.202 \\
\hline
\end{tabular}

Analysis of the results in most cases shows realization the unlinked channels W-migration. The probable continuous migration way of $\mathrm{W}$-ions (along [001]-axis) in picked crystals $[11,19]$ at RT carried out through "intermediate" voids what spaciously are not equivalent to regular positions of $\mathrm{W}$-ions.

\section{CONCLUSIONS}

The possible migration ways for the $\mathrm{W}$-ions in $\mathrm{PbWO}_{4}$ were visualized using the program package TOPOS. For some structural data at RT a possible continuous 3D-network of Wions migration is formed. The shape of the migration way and the void bounds are determined by method and technological conditions compound preparation and by temperature of investigated samples.

\section{REFERENCES}

[1] V. A. Blatov, "Multipurpose crystallochemical analysis with the program package TOPOS", IUCrCompCommNewsLetter, iss. 7, pp. 438, 2006.

[2] V. N. Shevchuk and I. V. Kayun, "Migration ways of ions in $\mathrm{CaMoO}_{4}$ and $\mathrm{BaWO}_{4}$ crystals with sheelite-type structure," Proc. Int. Conf. Oxide Materials for Electronic Engineering - fabrication, properties and applications OMEE-2014, Ukraine, pp. 117-118, May, 2014.

[3] V. N. Shevchuk and I. V. Kayun, "Analysis of electromigration and structure of $\mathrm{AWO}_{4}(\mathrm{~A}=\mathrm{Ca}, \mathrm{Cd}, \mathrm{Pb}, \mathrm{Zn})$ crystals using the TOPOS program complex", Chem. Met. Alloys, vol. 9, pp. 128-134, December 2016.

[4] V. N. Shevchuk and I. V. Kayun, "Influence of thermal prehistory on the electrical properties of tungstate crystals", Chem. Met. Alloys, vol. 4, pp. 72-76, June 2011.

[5] J.M. Moreau, Ph. Galez, J.P. Peigneux, and M. V. Korzhik, "Structural characterization of $\mathrm{PbWO}_{4}$ and related new phase $\mathrm{Pb}_{7} \mathrm{~W}_{8} \mathrm{O}_{(32-\mathrm{x})}$," J. Alloys and Comp., vol. 238, pp. 46-48, May 1996.

[6] D. Errandonea, J. Pellicer-Porres, F. J. Manjón, A. Segura, Ch. FerrerRoca, R. S. Kumar, O. Tschauner, J. López-Solano, P. RodríguezHernández, S. Radescu, A. Mujica, A. Muñoz, and G. Aquilanti, "Determination of the high-pressure crystal structure of $\mathrm{BaWO}_{4}$ and $\mathrm{PbWO}_{4}$," Phys. Rev. B, vol. 73, pp. 224103-1-224103-15, June 2006.

[7] Sh. Takai, T. Nakanishi, K. Oikawa, S. Torii, A. Hoshikawa, T. Kamiyama, and T. Esaka, "Neutron diffraction and IR spectroscopy on mechanically alloyed La-substituted $\mathrm{PbWO}_{4}$," Sol. St. Ionics, vol. 170, pp. 297-304, May 2004.

[8] Sh. Takai, Sh. Touda, K. Oikawa, K. Mori, Sh. Torii, T. Kamiyama, and T. Esaka, "Powder neutron diffraction study of Ln-substituted $\mathrm{PbWO}_{4}$ oxide ion conductors," Sol. St. Ionics, vol. 148, pp. 123-133, June 2002.

[9] R. Chipaux , G. Andre, and A. Cousson, "Crystal structure of lead tungstate at 1.4 and $300 \mathrm{~K}$,” J. Alloys and Comp., vol. 325, pp. 91-94, July 2001.

[10] Xu Kegin, Xue Jiyue, and Ding Yang, "Discovery of stolzite in China and refinement of its crystal structure," Acta Geologica Sinica, vol. 8, pp. 111-116, March 1995.

[11] L.S. Cavalcante, J.C. Sczancoski, V.C. Albarici, J.M.E. Matos, J.A. Varela, and E. Longo, "Synthesis, characterization, structural refinement and optical absorption behavior of $\mathrm{PbWO}_{4}$ powders," Materials Science and Engineering B, vol. 150, pp. 18-25, April 2008.

[12] R. Saraf, C. Shivakumara, S. Behera, H. Nagabhushana, and N. Dhananjaya, "Facile synthesis of $\mathrm{PbWO}_{4}$ : Applications in photoluminescence and photocatalytic degradation of organic dyes under visible light," Spectrochimica Acta Part A: Molecular and Biomolecular Spectroscopy, vol. 136, pp. 348-355, February 2015.

[13] A. Grzechnik, W. A Crichton, W. G Marshall, and K. Friese, "Highpressure X-ray and neutron powder diffraction study of PbWO4 and BaWO4 scheelites,” J. Phys.: Condens. Matter., vol. 18, pp. 3017-3029, March 2006.

[14] D. M. Trots, A. Senyshyn, and B. C. Shwarz, "Low temperature structural variation and heat capacity of stolcite $\mathrm{PbWO}_{4}$ ", J. Sol. St. Chem., vol. 183, pp. 1245-1251, June 2010.

[15] V. N. Shevchuk and I. V. Kayun, "Nano- and micro-size $\mathrm{V}_{2} \mathrm{O}_{5}$ structures", Chem. Met. Alloys, vol. 4, pp. 67-71, June 2011.

[16] "Pearson's Crystal Data - Crystal Structure Database for Inorganic Compounds", Release 2015/16, ASM International, Material Park, P. Villars and K. Cenzual, Eds., Ohio, USA.

[17] "Moden Crystallography", B. K. Vainshtein, Ed., vol. 2. Moscow: Nauka, 1979, p. 359.

[18] V. A. Blatov, "Voronoi-Dirichlet polyhedra in crystal chemistry: theory and applicaions", Crystallogr. Rev., vol. 10, pp. 249-318, April 2004.

[19] R. M. Hazen, L. W. Finger, and J. W. E. Mariathasan, "High-pressure crystal chemistry of sheelite-type tungstates and molibdates", J. Phys. Chem. Solids, vol. 46, pp. 253-263, Februar 1985. 